\title{
A Critical Analysis of Students' Performance within the 3-Year and 4-Year Secondary Education Policies in Ghana
}

\author{
Ollennu Samuel Nii Nmai \\ Faculty of Education and Entrepreneurship, Methodist University College Ghana, Ghana
}

Received February 12, 2020; Revised April 7, 2020; Accepted April 19, 2020

Copyright $\bigcirc 2020$ by authors, all rights reserved. Authors agree that this article remains permanently open access under the terms of the Creative Commons Attribution License 4.0 International License

\begin{abstract}
In its quest for an optimal education system, Ghana has implemented a number of education reform policies ending with the 3-year and 4-year secondary education systems. The main focus of this study was to use research findings to determine which system, between the 3 -year and 4-year secondary education policies, is optimal for Ghana. In the methodology, comparative analysis of secondary quantitative data in the form of test scores from the database of the West African Examinations Council was undertaken. The test scores were for the four core subjects, namely, English Language, Mathematics (Core), Integrated Science and Social Studies, for the period 2011 to 2015 within which the two policies operated equally. The difference in performance was subjected to Independent Sample T-test for statistical significance at $\mathrm{p} \leq .05$. The Cohen's $d$ effect size of the difference was also considered. Government subsidies for the two systems were examined. The study found that the 4-year secondary education system offers a better chance for academic performance, but the 3 -year system is economically more viable. Based on the findings, a 6-year primary, 2-year junior high and 4-year senior high $(6+2+4)$ pre-tertiary education system was proposed for the consideration of policymakers, without abolishing the 2-year kindergarten. A new framework for educational policy evaluation, is proposed. The author believes that the findings will contribute immensely to the search for an optimal secondary education policy for Ghana.
\end{abstract}

Keywords Optimal Education, Cost-Effectiveness, Academic Performance, Education Policy

\section{Introduction}

There is no argument against the fact that education is paramount for national development. In its efforts to catalyse national development, Ghana has implemented a number of education reform policies from pre-independence era ending with the recent 3-year and 4-year secondary education systems. This study sought to critically compare students' performance in the 3-year and 4-year secondary education systems in Ghana. The aim is to determine which one of the two systems offers a better academic performance for the country.

\section{Background}

Formal education in Ghana has its antecedents in the colonial era during which people were educated to provide personnel for running of the colonial administrative system [1]. During the immediate post-independence period, in a quest to fill gaps in the education system and develop appropriate manpower for national needs and the job market, successive governments in Ghana introduced a number of education policies. In the process, the National Redemption Council (NRC) which was a military government, introduced a 4-year second cycle education system in 1974 [23]. However, in 1987 the Provisional National Defense Council (PNDC), another military government, initiated the implementation of a pilot 3-year Junior Secondary School (JSS) and 3-year Senior Secondary School (SSS) education system. That government also proposed the abolition of the General Certificate of Education (GCE), Advanced and Ordinary levels examinations, bequeathed to Ghana by its colonial masters, the British. This 1987 Education Reform policy found its full implementation in 1993, and since then Ghana's senior secondary education assumed a three-year format. However, it was during this same era that the debate on whether Ghana should follow a 3-year or 4-year education system at the senior secondary level started after 
the first batch of students performed abysmally at the external standardised examination. The debate gathered momentum in 2002 when the Government of the New Patriotic Party (NPP) constituted a committee to gather information and make recommendations on which system to follow [10]. The discourse reached its zenith in 2006 when the NPP government declared its intention to introduce a 4-year senior secondary schooling system. The reform was finally introduced in 2008 and the 4-year secondary education system was started without change in the syllabus or subject combinations. But when the National Democratic Congress (NDC) took over the reins of government in 2009, it reverted to the 3-year secondary system ([18], [16]). Thus, between 2010 and 2013, both systems ran concurrently until the 4-year system ended in 2013. In that year, the last batch of the 4-year students took their final examination together with the first cohort of the re-introduced 3-year system. This revision in policy deepened the divide between the protagonists of the two systems.

According to GhanaWeb [11], education in Ghana is considered reasonably high. The education system in Ghana has an eleven-year basic schooling which starts with two years of kindergarten, six years of primary school and three years of junior high school (JHS). After JHS, students may choose to go into different streams at senior high school (SHS). The SHS streams comprise General Education, Technical, Vocational and Agricultural programmes. JHS graduates could also follow Technical and Vocational Education Training (TVET) or enter into an apprenticeship scheme [11]. To enter into SHS, students are required to sit for the Basic Education Certificate Examination (BECE) which is administered at the end of basic schooling. BECE qualifies students to enter SHS of their choice through the medium of the Computer School Selection and Placement System (CSSPS). In SHS, students are required to study eight subjects made up of four compulsory core subjects, and four elective subjects. The four core subjects are English Language, Integrated Science, Mathematics (Core) and Social Studies. The four elective subjects are selected based on the programme of choice which are General Science, General Arts, Business, Home Economics, Agriculture, Technical and Visual Art.

Currently, the SHS course runs for three years, at the end of which a student sits for the West African Senior School Certificate Examination (WASSCE). With an aggregate grade of 36 or better (that is, aggregates between 6-36) including at least a credit (Grade C6) in each of the core subjects, students could gain admission into a university, polytechnic, teacher training college, nursing training college or some other tertiary educational institution. At the moment, Ghana boasts of ten (10) public universities, ninty-one (91) private ones scattered all over the country and eight (8) technical universities. In addition, there are a number of other tertiary institutions which include forty-seven (47) colleges of education for teacher training, forty-six (46) degree nursing training institutions, twelve (12) chartered and professional institutions [17]. In fact, the growing number of universities and other tertiary educational institutions in Ghana does not only reflect the level of accessibility of education in the country, but also depicts the significant role Ghana plays in education in the West African region. This is substantiated by the presence of several students from countries within the sub-region in Ghanaian universities. The claim of high level of education might be the outcome of several education reform policies that Ghana has introduced.

\section{Statement of the Problem}

The tracing of Ghana's education reform trajectory ends currently with the 3-year and 4-year secondary education systems. The problem which surfaces in that trace is that there does not seem to be concrete research findings upon which the reform policies were formulated and implemented. As such, the debate on which of the two education systems is optimal for Ghana appears to be done without comparison of empirical data obtained from research on the performance of students in the two systems.

Meanwhile, one cannot deny that both the 3-year and 4-year education systems have advantages and disadvantages. Some of the advantages of the 3-year system include the fact that more graduates could be produced within a short time to meet the manpower requirements of the job market. Secondly, in the opinion of protagonists such as the National Democratic Congress (NDC), the 3-year system is less expensive when compared to the 4-year [18]. Furthermore, the protagonists claimed that the 3-year system did not elongate the stress of handling a particular cohort of students, should they appear to be boisterous. However, its major setback is that it negatively impacts on the time-on-task factor in teaching and learning [7]. The 4-year system offers a better prospect for the time-on-task factor in teaching and learning [7]. These pros and cons arguments show that there is a problem to be investigated.

\section{Objective of the Study}

This study had as its objective the critical comparison of secondary data in the form of test scores for the core subjects in the West African Senior School Certificate Examination (WASSCE) to determine where performance is higher between the 3-year and 4-year secondary education policies. The study also focused on which of the two policies is cost-effective and would bestow an optimal education system.

The aim of the study is to provide a quantitative research basis upon which policymakers could dwell to determine which of the two systems is better and would provide a stable secondary education system for Ghana. 


\section{Research Questions}

To achieve the objectives, the following research questions were raised for the study:

1. How comparable are candidates' performances in the 3-year and 4-year secondary education systems for the four core subjects - English Language, Mathematics, Integrated Science and Social Studies over a five year period $(2011-2015)$ ?

2. What statistical significant difference is there between the performance of students of the 3-year and 4-year secondary education systems?

3. How cost-effective are the 3-year and 4-year secondary education policies?

\section{Hypothesis}

In the determination of significant difference between the performances of students of the two systems, the following hypothesis was considered:

$\mathbf{H}_{\mathbf{0}}$ : The performances of candidates in the 3-year and 4-year system are the same.

$\mathbf{H}_{1}$ : The performances of candidates in the 3-year system and 4-year are not the same.

The outcome of the test for statistical significance will determine whether we reject the null hypothesis or fail to reject it.

\section{Literature Review}

According to Ruus et al. [24], educational reforms become of the essence when the curriculum and pedagogy turn obsolete and cease to meet the aspirations and socio-economic requirements of the country due to modernity and convergence of global demands. The scholars argued that in response to the phenomena of modernity and globalization, the aim, content and organisation of education are thoroughly changed, and curriculum reform is rapidly implemented. To substantiate this, Cheng [2] stated that to meet the challenge of globalization, economic transformation, and international competitions in the new century, there have been numerous educational reforms and initiatives in many countries in the Asia-Pacific Region and other parts of the world.

Ghana has not been spared the compulsions which are driven by technology and globalization in the contemporary era [15]. Neither has it been insulated from the rapid changes which have characterised modernity [14] and eventuated educational reforms. Like the Asia-Pacific countries, Ghana has implemented several educational reforms. Documentation of reforms in the history of formal education in Ghana covers both the pre- and post-independence eras [28]. One such reform introduced in 2007 elongated the SHS duration from three years to four years, and this came into effect in 2008. Arguing in support of the 4-year secondary system, Djangmah and Akyeampong [7] stated that the 4-year system offers a better time-on-task factor for teaching and learning and gives ample opportunity to weaker students to catch up. The researchers further contended that the three-year senior secondary schooling impacted more negatively on the public-school children who were in the majority. They stated that as long as public schools remain inadequate in staffing quality and quantity, and also in teaching and learning resources, students who attend those schools will continue to be at a disadvantage. Though increasing the duration of the senior high school (SHS) will require additional resources, the researchers argued that it will allow extra time to correct the deficiencies in the reading and writing skills of the students. Djangmah and Akyeampong [7] emphasized that additional state resource utilised to improve the performance of the majority of Ghanaian children is money well spent to minimise inequality in access to educational opportunity. The duo suggested that as solutions, the authorities of the Ministry of Education at the time, should have pushed for a reduction in the standard of the WAEC examination to a level which the majority of pupils could cope with after three years in SHS or allowed high achievers to do SHS in three years while the majority did it in four years. Djangmah [8], however, agrees that expenditure in keeping the students in school for longer periods could be exorbitant, and employers may have to wait a little longer to make their selection of manpower.

Kale-Dery [13] reports that, in a similar argument in support of the 4-year system, Prof. J. A. Fletcher, Deputy Director of the School of Teacher Education of the University of Cape Coast, Ghana posited that the general low performance in Mathematics in Ghanaian secondary schools may be ascribable to the limited time allotted for the subject due to the shortness of the learning period precipitated by the 3-year secondary education system. Nonetheless, a fact that may reduce the potency of Fletcher's argument is that in the 2013 version of the Excellence Awards for top performing candidates of WASSCE in the West African sub-region given by WAEC, the first position was taken by a student who was a product of the 3-year system; while the second and third positions were picked by products of the 4-year system [13]. Students of both education systems took the examination at the same time in 2013. Kale-Dery [13] further reports that dwelling on the occurrence in which a 3-year product beat the 4-year products at the same examination, Mr. C. Aheto-Tsegah, the then Acting Director-General of the Ghana Education Service, argued that duration of schooling was neither here nor there as far as good academic performance was concerned. Instead, it depends on provision of good teaching materials and a conducive atmosphere for learning. 
In a compromise stance, Yankah [27] argued for a concurrent implementation of the 3-year and 4-year secondary education policies to address challenges faced by the less-endowed schools. The scholar stated that lessons learnt from the implementation of the two regimes show that while the well-endowed schools performed better in the 3-year cycle, the less-endowed ones did poorly. He said that the less-endowed ones performed relatively well under the 4-year cycle. In calling for a side-by-side implementation of the two regimes, Yankah [27] opined that the well-endowed schools should not be denied the option of pursuing a 3-year cycle; neither should the less-endowed ones be refused the chance to opt for a 4-year term. The researcher asserted that examination malpractices were higher during the final examination written at the end of the 3-year term compared to the 4-year. He attributed this occurrence to the stress and anxiety arising from inadequacy of time that students require for study and preparation for the examination. In his conclusion, Yankah [27] advocated for the implementation of a dual system which would ensure that students who can make it in three years do so, while the others, especially those from the less advantaged schools, venture theirs in four years. The discussant said by doing so, a flexible system would be created where those who stood disadvantaged would not be in an unfair competition with others who might be better placed. He conceded however, that the implementation of the dual system would require an enlargement of the capacity of the senior high schools in terms of infrastructure, teaching-learning materials and personnel.

Regarding what an optimal education system is, Glewwe and Muralidhara [12] posited that given the tight fiscal constraints under which governments of developing countries operate, a key issue for them is to identify the most cost-effective ways of achieving positive education, and to identify the policies that are less cost-effective for possible abolishment. The researchers argued that an educated populace is necessary- though not necessarily sufficient- for long-term economic growth and, more generally, a high standard of living. Additionally, they stated that there is ample evidence that in many developing countries children learn much less than the goals set out in the official curriculum. However, there is the need for children to acquire the human capital that their schooling should provide. In support of the cost-effective factor, Covey [5] asserted that one factor which can quickly bring down a company is poor cost management and also, the viability or success of any enterprise has a very strong correlation with managing and reducing cost. Thus, it is important to keep an eye on cost when formulating an education policy, be it for a 3-year or 4-year duration.

There is no gainsaying the claim that education is paramount to the creation of a sound knowledge base and training of essential human resources required for socio-economic advancement and development of a nation. A country's educational system is therefore the critical link that enables the development of human capital to adapt to existing science and technology, and to develop new solutions for local developmental challenges [20]. As such, the prevailing global climate provides motivation for dynamic reaction to the needs of change in education. In the framework of globalization, the easiest way to implement reforms is to borrow the solutions that have been developed and implemented in other countries [9]. However, Eisenschmidt and Niglas [9] posited that the introduction of borrowed reforms tend to be rather unsuccessful in processes where there are many partners involved. This is more so when the various aspects of the context, including the social as well as the cultural background and traditions of the particular country have not been taken into account. The scholars opined that it would be more meaningful if the decisions to formulate policies for educational reforms were based on wide consultation and findings of systematic research activities. The drive for generating empirical data from a systematic research to facilitate consultations on whether the secondary education system of Ghana should last for three or four years is what provides the impetus for this study.

\section{Research Methodology}

The study was a descriptive research which employed a quantitative approach involving a comparative analysis in a cross-sectional design. The comparative analysis was employed to identify differences in performance between the two education systems under investigation, that is, the 3-year and 4-year secondary education systems. The population was made of all students who registered for WASSCE from 2011 to 2015 in Ghana. This period was selected because within it the two policies were operated for equal number of years. The sample was made of candidates who actually sat for the English Language, Integrated Science, Mathematics (Core), and Social Studies tests in Ghana. The choice of these subjects was informed by the fact that they were compulsory, and therefore common to all students of the period in question. It is also noteworthy that during that period, the curriculum and scheme of subject selection and examination were not changed. Therefore, the two groups derived for the period 2011-2015 received the same treatment.

During the data analysis, the variances in performance were tested for statistical significance at $\mathrm{p} \leq .05$ using Independent Sample T-tests. The effect size of the difference in performance was determined using Cohen's $d$ values.

To compare the cost of running the two systems, a comparative analysis of figures for government subsidy for senior high schools for the period was undertaken. 


\section{Quantitative Data Collection}

The quantitative data used for the study was secondary data in the form of test scores obtained from the database of the West African Examinations Council (WAEC) which is the body mandated to conduct WASSCE. The statistics obtained include:

1. the education system in operation in a particular year;

2. the candidature- separated for male and female testees;

3. the test scores- highest score, mode, mean and standard deviation;

4. the pass rate- Grades A1-C6 cumulated;

5. the number of candidates qualifying for the Excellence Award presented by WAEC.
It is important to mention that in 2013, both cohorts of the 3-year and 4-year systems wrote the same papers of WASSCE together. Thus, the only difference between the two cohorts is the duration of instruction. This makes 2013 a unique year for WASSCE and a kind of control for the study.

\section{Results Presentation}

\subsection{Test Scores Related Data}

The collections of the quantitative data are tabulated in Table 1 for English Language, Table 2 for Mathematics (Core); Table 3 for Integrated Science; and Table 4 for Social Studies.

Table 1. Quantitative Data for English Language

\begin{tabular}{|c|c|c|c|c|c|c|c|}
\hline \multicolumn{2}{|l|}{ Year } & 2011 & 2012 & 2013 & 2013 & 2014 & 2015 \\
\hline \multicolumn{2}{|c|}{ Education System } & 4-year & 4-year & 4-year & 3 -year & 3 -year & 3 -year \\
\hline \multirow{3}{*}{ Candidature } & Male & 81,470 & 95,203 & 114,615 & 106,231 & 126,920 & 139,868 \\
\hline & Female & 67,334 & 79,253 & 97,221 & 91,675 & 115,243 & 128,944 \\
\hline & Total & 148,804 & 174,456 & 211,836 & 197,906 & 242,163 & 268,812 \\
\hline \multirow{4}{*}{ Scores } & Highest Score & 84 & 84 & 83 & 82 & 78 & 81 \\
\hline & Mode Score & 45 & 46 & 43 & 43 & 38 & 40 \\
\hline & Mean Score & 43.60 & 44.37 & 42.82 & 41.86 & 38.33 & 39.46 \\
\hline & Std. Dev. & 9.66 & 10.36 & 8.96 & 9.02 & 9.38 & 9.73 \\
\hline \multirow{2}{*}{$\begin{array}{l}\text { Pass Rate } \\
\text { (A1 - C6) }\end{array}$} & Frequency & 112,653 & 118,927 & 142,890 & 124,669 & 108,638 & 133,973 \\
\hline & Percentage & 77.71 & 68.17 & 67.45 & 62.99 & 44.86 & 49.84 \\
\hline
\end{tabular}

Table 2. Quantitative Data for Mathematics (Core)

\begin{tabular}{|c|c|c|c|c|c|c|c|}
\hline \multicolumn{2}{|l|}{ Year } & 2011 & 2012 & 2013 & 2013 & 2014 & 2015 \\
\hline \multicolumn{2}{|c|}{ Education System } & 4-year & 4-year & 4-year & 3-year & 3-year & 3-year \\
\hline \multirow{3}{*}{ Candidature } & Male & 81,431 & 95,188 & 114,595 & 106,206 & 126,884 & 139,839 \\
\hline & Female & 67,326 & 79,240 & 97,214 & 91,660 & 115,226 & 128,929 \\
\hline & Total & 148,757 & 174,428 & 211,809 & 197,866 & 242,110 & 268,768 \\
\hline \multirow{4}{*}{ Score } & Highest Score & 99 & 99 & 99 & 99 & 99 & 99 \\
\hline & Mode Score & 34 & 36 & 31 & 31 & 26 & 18 \\
\hline & Mean Score & 37.86 & 40.17 & 35.54 & 33.75 & 33.72 & 29.27 \\
\hline & Std. Dev. & 15.82 & 16.46 & 15.18 & 14.52 & 14.88 & 14.28 \\
\hline \multirow{2}{*}{$\begin{array}{l}\text { Pass Rate } \\
(\mathrm{A} 1-\mathrm{C6})\end{array}$} & Frequency & 64,986 & 86,742 & 82,086 & 67,079 & 77,882 & 64,264 \\
\hline & Percentage & 43.69 & 49.73 & 38.75 & 33.90 & 32.17 & 23.91 \\
\hline
\end{tabular}


Table 3. Quantitative Data for Integrated Science

\begin{tabular}{|c|c|c|c|c|c|c|c|}
\hline \multicolumn{2}{|l|}{ Year } & 2011 & 2012 & 2013 & 2013 & 2014 & 2015 \\
\hline \multicolumn{2}{|c|}{ Education System } & 4-year & 4-year & 4-year & 3-year & 3 -year & 3 -year \\
\hline \multirow{3}{*}{ Candidature } & Male & 81,432 & 95,188 & 114,595 & 106,206 & 126,884 & 139,836 \\
\hline & Female & 67,326 & 79,240 & 97,214 & 91,660 & 115,226 & 128,929 \\
\hline & Total & 148,758 & 174,428 & 211,809 & 197,866 & 242,110 & 268,765 \\
\hline \multirow{4}{*}{ Score } & Highest Score & 95 & 95 & 94 & 93 & 92 & 91 \\
\hline & Mode Score & 43 & 46 & 40 & 38 & 29 & 26 \\
\hline & Mean Score & 45.37 & 46.76 & 43.98 & 41.71 & 34.16 & 33.10 \\
\hline & Std. Dev. & 14.08 & 13.59 & 14.57 & 14.37 & 13.24 & 13.72 \\
\hline \multirow{2}{*}{$\begin{array}{l}\text { Pass Rate } \\
\text { (A1-C6) }\end{array}$} & Frequency & 62,301 & 98,679 & 111,803 & 90,836 & 68,970 & 62,374 \\
\hline & Percentage & 41.88 & 56.57 & 52.78 & 45.91 & 28.49 & 23.21 \\
\hline
\end{tabular}

Table 4. Quantitative Data for Social Studies

\begin{tabular}{|c|c|c|c|c|c|c|c|}
\hline \multicolumn{2}{|l|}{ Year } & 2011 & 2012 & 2013 & 2013 & 2014 & 2015 \\
\hline \multicolumn{2}{|c|}{ Education System } & 4-year & 4-year & 4-year & 3-year & 3-year & 3-year \\
\hline \multirow{3}{*}{ Candidature } & Male & 81,471 & 95,205 & 114,615 & 106,233 & 126,920 & 139,868 \\
\hline & Female & 67,334 & 79,256 & 97,220 & 91,677 & 115,243 & 128,944 \\
\hline & Total & 148,805 & 174,461 & 211,835 & 197,910 & 242,163 & 268,812 \\
\hline \multirow{4}{*}{ Score } & Highest Score & 93 & 94 & 91 & 91 & 93 & 88 \\
\hline & Mode Score & 67 & 68 & 66 & 60 & 48 & 46 \\
\hline & Mean Score & 61.33 & 62.98 & 59.68 & 55.94 & 48.05 & 45.26 \\
\hline & Std. Dev. & 12.08 & 11.70 & 12.45 & 12.53 & 13.91 & 13.82 \\
\hline \multirow{2}{*}{$\begin{array}{l}\text { Pass Rate } \\
\text { (A1 - C6) }\end{array}$} & Frequency & 121,974 & 151,978 & 175,556 & 155,701 & 137,710 & 137,832 \\
\hline & Percentage & 81.97 & 87.11 & 82.87 & 78.67 & 56.87 & 51.27 \\
\hline
\end{tabular}

Table 5. Quantitative Data for Excellence Award

\begin{tabular}{|c|c|c|c|c|c|c|c|}
\hline \multirow{3}{*}{ Excellence Award } & Year & $\mathbf{2 0 1 1}$ & $\mathbf{2 0 1 2}$ & $\mathbf{2 0 1 3}$ & $\mathbf{2 0 1 3}$ & $\mathbf{2 0 1 4}$ & $\mathbf{2 0 1 5}$ \\
\cline { 2 - 9 } & Education System & 4-year & 4-year & 4-year & 3-year & 3-year & 3-year \\
\cline { 2 - 9 } & Frequency & 84 & 529 & 96 & 55 & 62 & 112 \\
\cline { 2 - 9 } & Percentage & 0.06 & 0.30 & 0.05 & 0.03 & 0.03 & 0.04 \\
\hline
\end{tabular}

From Table 1, the mean percentage scores of the 4-year students for the period under consideration were better than those of the 3-year in English Language. Though the mean score for the 4-year dipped in 2013, it was still better than that of the 3 -year for the same year. Table 2 also shows that the mean percentage scores of the 4-year students were again better than those of the 3-year in Mathematics (Core). Nonetheless, the 4-year cohort showed a fluctuating trend while the 3-year group showed a declining trend in performance. The trends for Integrated Science and Social Studies are the same as that for Mathematics as depicted in Table 3 and Table 4.

From Table 5, data for those qualifying for the award within the era of the 4-year system showed a fluctuating trend, while those of the 3-year had an increasing trend. However, the total number of students who were qualified for the excellence award within the era of the 4-year system surpassed that of those who were qualified during the period of the 3-year system.

\subsection{Data on Running Cost of the Two Education Systems}

To ascertain the cost effectiveness of the two systems, the annual government subsidies for support of the senior high schools were obtained. The figures were obtained from the Ministry of Education (MOE) of Ghana for the period $2011-2015$, and are presented in Table 6 below: 
Table 6. Government Remittance to SHSs

\begin{tabular}{|c|c|c|c|}
\hline Year & Education System & Candidature & Amount (GHC) \\
\hline $\mathbf{2 0 1 1}$ & 4-year & 148,804 & $30,000,000.00$ \\
\hline $\mathbf{2 0 1 2}$ & 4-year & 174,456 & $41,931,957.00$ \\
\hline \multirow{2}{*}{2013} & \multirow{3}{*}{ 4-year \& 3-year } & 4-year $=211,835$ & 4-year $=43,493,960.28$ \\
\cline { 3 - 4 } & & 3-year $=197,911$ & 3-year $=40,635,084.72$ \\
\hline \multirow{2}{*}{$\mathbf{2 0 1 4}$} & 3-year & Total $=409,746$ & Total $=84,129,045.00$ \\
\hline $\mathbf{2 0 1 5}$ & 3-year & 242,163 & $67,050,218.10$ \\
\hline
\end{tabular}

The figure for 2013 was given as a bulk amount of GHC84,129,045.00 for the total number of students for both the 3-year and 4-year systems, that is, 409,746. To obtain the separate figures for the two systems, simple ratio was used. From the figures in Table 6, expenditure of government, in terms of subsidy to secondary schools for the period under investigation, showed an increasing trend for the 4-year system, and a generally decreasing trend for the 3-year system.

\section{Deductions from the Tables}

An attempt is now made to glean for further information from figures in Tables 1, 2, 3, 4 and 5 above.

\subsection{Education System}

From Tables 1 to $\mathbf{5}$, it is clear that the education systems in operation were the 4-year for the period 2011 to 2013 and the 3-year for 2013 to 2015. In 2013, there was an overlap and both cohorts took the final examination at the same time. Year 2013 therefore served as a kind of common ground for the comparison of performance of the two groups.

\subsection{Candidature}

The candidature figures were for those who actually sat for the tests. Those who registered for the examination but were absent for whatever reason, were not included in the figures. It may be observed from the tables that the candidatures of the males were higher than those of the females in all the subjects across all the years.

\subsection{Test Scores}

The averages of the highest scores for each of the systems are presented in Table 7 .

Judging from the figures in Table 7 it is obvious that the averages of the highest scores obtained by candidates during the period under review, were higher for the 4-year system than the 3 -year. If these were to be used as a measure of performance, then one could postulate that the general performance in the 4-year system was better than that of the 3-year. Similarly, the trend for the mode scores followed that of the highest scores, in that, those for the 4-year system were higher than those for the 3-year as shown in Table 8.

Table 7. Averages of the Highest Scores

\begin{tabular}{|l|c|c|}
\hline Subject & 4-Year & 3-Year \\
\hline English Language & 83.67 & 80.33 \\
\hline Mathematics & 99.00 & 99.00 \\
\hline Integrated Science & 94.67 & 92.00 \\
\hline Social Studies & 92.67 & 90.67 \\
\hline
\end{tabular}

Table 8. Averages of the Modes

\begin{tabular}{|l|c|c|}
\hline Subject & 4-Year & 3-Year \\
\hline English Language & 44.67 & 40.33 \\
\hline Mathematics & 33.67 & 25.00 \\
\hline Integrated Science & 43.00 & 31.00 \\
\hline Social Studies & 67.00 & 51.33 \\
\hline
\end{tabular}

In Table 9, the averages of the mean scores are given and they present a similitude of the highest scores and modes.

Table 9. Averages of the Mean Scores

\begin{tabular}{|l|c|c|}
\hline Subject & 4-Year & 3-Year \\
\hline English Language & 43.60 & 39.88 \\
\hline Mathematics & 37.86 & 32.25 \\
\hline Integrated Science & 45.37 & 36.32 \\
\hline Social Studies & 61.33 & 49.75 \\
\hline
\end{tabular}

Table 10. Averages of the Standard Deviation

\begin{tabular}{|l|c|c|}
\hline Subject & 4-Year & 3-Year \\
\hline English Language & 9.66 & 9.38 \\
\hline Mathematics & 15.82 & 14.56 \\
\hline Integrated Science & 14.08 & 13.78 \\
\hline Social Studies & 12.07 & 13.42 \\
\hline
\end{tabular}

The standard deviation gives an indication of the spread from the mean score and it was highest in Mathematics (Core), followed by Integrated Science and lowest in 
English Language, with Social Studies taking a leap over English Language. The averages for the two systems are given in Table 10.

From Table 10, one can judge that the difference between the high performers and the low achievers was least in English Language for both the 4-year and 3-year systems, though that of the 4-year was slightly higher for that subject. Mathematics presented the highest difference between the extreme-end performers for both the 4-year and 3-year, with the 4-year being higher than the 3-year system. This was confirmed by the statistics of the best highest score occurring in Mathematics and the worst mode score also in the same subject for both systems. The results also showed that with more time, the disparity between the high achievers and the low performers may increase since the standard deviations are generally higher in the 4-year system than the 3-year. The implication therefore is that with increased number of years in school, the good students may widen the gap between them and the low achievers. Thus, the perceived levelling effect of duration in schooling by the 4-year system proponents may not be the case, especially, for performance in Mathematics.

\subsection{Pass Rate in Subject}

The pass rate was determined as a percentage of those who obtained credit grades, i.e. Grades A1 to C6, against the total candidature for a subject. For the purpose of comparison, the average pass rates are tabulated in Table 11.

From Table 11, the averages of the pass rates for Social Studies were highest for both systems and lowest for Mathematics, again for both systems. The status from the figures in the table showed that the pass rate in the 4-year system was better than that of the 3 -year system for all the subjects under consideration. This means that more candidates qualified for tertiary education in Ghana during the era of the 4-year than the 3-year system.

Table 11. Averages of the Pass Rates (\%)

\begin{tabular}{|l|c|c|}
\hline Subject & 4-Year & 3-Year \\
\hline English Language & 71.11 & 52.56 \\
\hline Mathematics & 44.06 & 29.99 \\
\hline Integrated Science & 50.41 & 32.54 \\
\hline Social Studies & 83.98 & 62.27 \\
\hline
\end{tabular}

\subsection{Excellence Award}

The Excellence Award, as stated earlier, is given by WAEC to the first three best performing candidates at WASSCE in the Anglophone West African sub-region. For candidates to qualify for this award, they must obtain Grade A1 in all the eight subjects taken at the examination. Thus, the general performance in a year at the examination for any of the education systems will definitely have a direct correlation with the number of candidates who qualify for the Award. This number can therefore be relied upon to judge and compare performance since this statistic is a conglomerate of data from all the subjects under consideration. The figures for the statistic are presented in

\section{Table 12.}

The calculated average of percentages qualifying for the Excellence Award was $0.14 \%$ for the 4 -year, and then $0.03 \%$ for the 3-year, within the periods that each system operated. By these statistics, the academic performance of the 3-year system was lower than that of the 4-year. However, information from WAEC indicates that in 2013, though more students from the 4-year system qualified for the award, the overall best performing candidate for the year came from the 3-year cohort.

Table 12. Figures for Excellence Award

\begin{tabular}{|l|c|c|c|c|c|c|c|}
\hline \multicolumn{2}{|l|}{ Year } & $\mathbf{2 0 1 1}$ & $\mathbf{2 0 1 2}$ & $\mathbf{2 0 1 3}$ & $\mathbf{2 0 1 3}$ & $\mathbf{2 0 1 4}$ & $\mathbf{2 0 1 5}$ \\
\hline \multicolumn{2}{|l|}{ Education System } & 4-year & 4-year & 4-year & 3-year & 3-year & 3-year \\
\hline \multirow{3}{*}{ Excellence Award } & Frequency & 84 & 529 & 96 & 55 & 62 & 112 \\
\cline { 2 - 9 } & Percentage & 0.06 & 0.30 & 0.05 & 0.03 & 0.03 & 0.04 \\
\cline { 2 - 9 } & \multicolumn{3}{|c|}{ Average } & \multicolumn{3}{|c|}{0.14} & \multicolumn{3}{|c|}{0.03} \\
\hline
\end{tabular}




\subsection{Grand Pass Rate for Tertiary Education}

In Ghana, qualification for tertiary education is determined mainly by passes at WASSCE. Specifically, a candidate must obtain Grades A1 to C6 in six subjects at WASSCE to qualify. The combination of the passes must of necessity be in three core subjects, that is, English Language, Mathematics (Core) and Integrated Science or Social Studies, and three elective subjects. This works out to an aggregate of 36 or better (i.e. Aggregate 6-36).

Apart from using these criteria as qualification for admission into tertiary institutions, the outcomes were used as a barometer for measuring general performance and also used to determine whether standard of education was improving or declining over the years. Thus, figures from this barometer over the period under review give a reasonable indication of the trajectory of academic performance, and hence, the reference to it as the Grand Pass Rate. Table 13 gives the Grand Pass Rates for qualification into tertiary education over the period under investigation.

Table 13 shows that the Grand Pass Rates of the 4-year system were higher than those of the 3-year. This gives an indication that performance in the 4-year system was better than that of the 3-year. It further goes to suggest that more candidates qualified to undertake tertiary educational programmes during the 4-year era than what obtained in the 3-year era.

Figure 1 gives a graphical representation of the Grand Pass Rate trends of the two systems.

Table 13. Grand Pass Rate for Tertiary Education

\begin{tabular}{|c|c|c|c|c|c|c|}
\hline Year & System & Entry Figure & Absentee & No. Sat & Pass Rate Frequency (A1-C6) & Pass Rate Percentage (A1-C6) \\
\hline 2011 & 4-year & 148,805 & 426 & 148,379 & 56,643 & 38.17 \\
\hline 2012 & 4-year & 174,461 & 610 & 173,851 & 73,307 & 42.17 \\
\hline 2013 & 4-year & 211,835 & 1,184 & 210,651 & 66,344 & 31.49 \\
\hline 2013 & 3-year & 197,911 & 1,096 & 196,815 & 52,353 & 26.60 \\
\hline 2014 & 3-year & 242,159 & 1,635 & 240,524 & 68,474 & 28.47 \\
\hline 2015 & 3-year & 268,812 & 1,118 & 267,694 & 45,070 & 16.84 \\
\hline
\end{tabular}

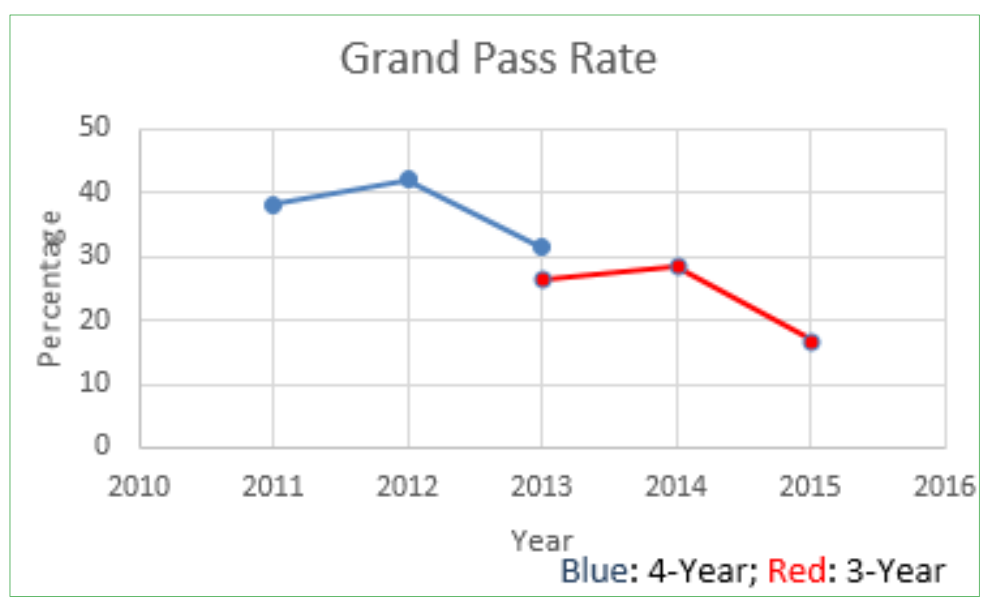

Figure 1. Trends of Grand Pass Rate for Tertiary Education 


\subsection{Results of Test for Significance in Variance of Performance}

In order to ensure that the variances in the observed test scores were not spurious, statistical tests were performed on the mean scores. The outcome of the test is presented below.

\subsubsection{Independent Samples T-Test}

Independent Samples T-Test was conducted to compare the mean scores of candidates in English Language, Mathematics (Core), Integrated Science, and Social Studies for the 3-year and 4-year secondary education systems. The results of the analysis are presented in Table 14 and Table 15.

Table 14. Group Statistics for the 3-year (2013, 2014 and 2015) and 4-Year (2011, 2012, and 2013) Education Systems

\begin{tabular}{|l|c|c|c|c|}
\hline Subjects & Education System & N & M & SD \\
\hline \multirow{2}{*}{ English language } & 3-year & 3 & 39.88 & 1.8 \\
\cline { 2 - 5 } & 4-year & 3 & 43.6 & 0.77 \\
\hline \multirow{2}{*}{$\begin{array}{l}\text { Mathematics } \\
\text { core) }\end{array}$} & 3-year & 3 & 32.4 & 2.3 \\
\cline { 2 - 5 } & 4-year & 3 & 37.85 & 2.32 \\
\hline \multirow{2}{*}{ Integrated Science } & 3-year & 3 & 36.32 & 4.7 \\
\cline { 2 - 5 } & 4-year & 3 & 45.36 & 1.39 \\
\hline \multirow{2}{*}{ Social Studies } & 3-year & 3 & 49.75 & 5.54 \\
\cline { 2 - 5 } & 4-year & 3 & 61.33 & 1.65 \\
\hline
\end{tabular}

$\mathrm{N}=$ the No. of years in each category

Table 15. Independent-Samples T-Test for the 3-Year $(2013,2014$, and 2015) and 4-Year (2011, 2012, and 2013) Education Systems

\begin{tabular}{|l|c|c|c|c|}
\hline Subject & $\mathbf{t}$ & $\mathbf{d f}$ & Sig (2-tail) & $\begin{array}{c}\text { Cohen's d } \\
\text { (Effect Size) }\end{array}$ \\
\hline English Language & -3.28 & 4 & $.03^{*}$ & 2.68 \\
\hline $\begin{array}{l}\text { Mathematics } \\
\text { (Core) }\end{array}$ & -2.89 & 4 & $.04 *$ & 2.36 \\
\hline Integrated Science & -3.19 & 4 & $.03^{*}$ & 2.61 \\
\hline Social Studies & -3.47 & 4 & $.02 *$ & 2.83 \\
\hline
\end{tabular}

*the test is significant at 0.05 level.

Candidates' scores for the six groups of candidates were categorised into the 3-year and 4-year secondary education systems. This became the categorical or independent variable. The continuous or the dependent variable was the average scores for candidates in the various subjects for each group. The data did not violate the assumptions of equality of variances. In other words, the variations in scores for the groups in all the subjects were the same.

The analysis showed a statistically significant difference between the mean scores of the two groups in all the four subjects. This was also evident in the mean scores which favoured the 4-year programme in all subjects. For instance, in English Language, there was a statistically significant difference in the mean scores of candidates between the 3-year $(M=39.88, S D=1.80)$ and 4-year $[M=43.60, S D$ $=.77 ; t(6)=-3.28, p=.03$ ] education systems. To determine the status of the statistical significance of the differences in the mean scores, the Cohen's $d$ effect size was considered. By the test, the magnitude of the differences for all the four subjects was huge (Cohen's d > 2.0).

\subsubsection{Hypothesis}

We may now consider the hypothesis proposed for the study:

$\mathbf{H}_{\mathbf{0}}$ : The performances of candidates in the 3-year and 4-year system are the same.

$\mathbf{H}_{1}$ : The performances of candidates in the 3-year system and 4-year are not the same.

The results of the statistical tests reveal a statistically significant difference between the performance of the candidates of the 3-year and 4-year secondary education systems. Therefore, from the test for statistical significance, the null hypothesis is rejected. Since it is a two-tail test, we can now depend on the mean scores to postulate that performance during the 4-year era was significantly higher than that of the 3-year era.

\subsection{Summary of Deductions}

For all the quantitative parameters, that is, scores, pass rates, excellence award qualifiers, and grand pass rates for tertiary education, the performance of candidates during the 4-year era surpassed that of the 3-year. The result of test of significance in variance of performance also favoured the 4-year system. Thus, should one depend upon the quantitative analysis to pass judgment on performance, it could be said that the 4-year system is more advantageous than the 3-year. However, considering the government subsidy figures from MOE, the 3-year secondary education system appears to be more cost effective to run.

\section{Discussion}

It may be observed from Tables $\mathbf{1}$ to $\mathbf{4}$, that the candidatures of the males who sat for WASSCE were higher than those of the females in all the subjects across all the years. This was not surprising as it followed the general historical trend in student-gender categorization in Ghana [8]. In the early 1980 s, to partially address the wide gender disparity which existed between males and females in the general student population in the country, a programme dubbed "Send Your Girl-Child to School" was pursued to breach the gap between males and females among school-going youth of the time.

It is also observable that the number of candidates taking the examination increased sturdily for all the subjects across the years and almost doubled from 2011 to 2015 . This could be as a result of interventions put in place by the 
Ghanaian government. These interventions include the School Feeding Programme, Capitation Grant, construction of more community day senior high schools, and general improvement in infrastructure and supply of equipment in the schools. The general increase in the population of the country may also have contributed to the observed increasing trend in the candidatures. According to Trading Economics [25], the population of Ghana increased from 25.39 million in 2011 to 27.85 million in 2015.

The analysis of the WASSCE results for the selected years showed that the general performance of students of the 4-year system was better than that of the 3-year, which is in sync with the rejection of the null hypothesis. Considering the performances based on the mean scores and pass rates between the two systems for instance, the antagonists of the 4-year may not deny the fact that the 3 -year system is less advantageous in terms of academic performance. Thus, if one were to depend upon the quantitative analysis to pass judgment, then the protagonists of the 4-year secondary education policy would carry the day. This may sit well with Walsh [26] who documented that in the modern secondary school in Great Britain, the students attended a four-year course leading to an examination for the award of School Leaving Certificate. The four-year secondary education was maintained when the Comprehensive School system was instituted in Great Britain. In that system, students sat for the General Certificate of Secondary Education (GCSE) after four years of study. Davis and Jordan [6] also indicated that the American school structure has four years of high school education.

However, Japan, Hong Kong and Nigeria all run a three-year secondary education policy [4], [3], [19] just like Ghana currently does. One can infer that in spite of the statistical evidence which stands in favour of the 4-year secondary education system, the protagonists of the 3-year system may be right in their assertion that there are other factors to be considered in the determination of a secondary education policy for a country. These factors include reduction of school duration to obtain longer working years, and cheaper financing. Arguably, such factors are equally weighty issues beside academic performance. Since a government cannot spend the money it does not have on education, it stands to reason that the economics of the system may be placed highest in the order of considerations. In this connection, Glewwe and Muralidhara [12] posited that given the tight fiscal constraints under which governments of developing countries such as Ghana operate, a key issue for them is to identify the most cost-effective ways of achieving positive education and pursue those, whilst identifying the policies that are less cost-effective for possible abolishment. In that sense, Table 6 shows that indeed, the Ghanaian 3-year secondary education policy is more cost-effective than the 4-year system. This may account for the reason why Ghana reverted to the 3-year secondary education system after a three-year try with the 4-year system.

Yankah [27] proposed a hybrid secondary education policy in which students who are ready in three years should be permitted to write the final examination and move ahead, whilst those who would need more time are not denied the one-year-extra necessity. However, in the view of the author of this study, the challenge which a three-cum-four-year hybrid system may face is whether to spread the topics in the syllabus to cover three years of learning or four years, since students of both options may be in the same school or even in the same classroom. In a case where the syllabus is spread over three years, the 4-year cohort would be potentially redundant in the fourth year. On the other hand, should the syllabus be spread over four years, the 3-year cohort may not have covered all the syllabus to make them adequately prepared for the final examination at the end of the third year. Therefore, further discussions on a three-cum-four-year hybrid secondary education system may be necessary before its implementation.

\subsection{Framework for Optimal Education System}

As part of its objectives, the study sought to ascertain which one of the two systems is better in terms of cost-effectiveness, and would provide optimal education for the Ghanaian child. Conscious of the work of Glewwe and Muralidhara [12], the author of this research defines an optimal education system as follows:

An optimal education system is the one that is cost-effective and does not place undue pressure on existing resources; it is the one that produces good academic performance due to effective teaching and learning to attain goals set in the curriculum, increases the human capital of its graduates to churn out the requisite manpower with problem-solving abilities for the job market; and finally, it is the education system that yields high standard of living for the citizenry.

It is to this kind of desirable system that the author of this study equates an optimal secondary education system.

The efficacy of the 3-year and 4-year secondary education systems may also be compared by dwelling upon the definition of optimal education system given for this study and the results of the research. For this exercise, the identifiable characteristics in the definition are:

i) Cost-effectiveness;

ii) Low stress on existing facilities;

iii) Little additional resources required;

iv) Higher academic performance;

v) Increased human capital of graduates;

vi) Imparting of problem-solving abilities;

vii) High living standard of citizenry.

In respect of cost-effectiveness, it may be observed from the research results that the 3-year policy is more 
affordable than the 4-year. In this connection, Covey [5] opined that there is a strong correlation between the viability or success of any enterprise and managing and reducing cost. He also stated that a company could easily be brought down to its knees through poor cost management. In the same vein, Levitt [14] postulated that the influence of multinational companies would continue to diminish giving way to the growth of more global companies. He explained that this is because global companies have found a cost-effective way of producing same commodities across the globe, and offering them for cheaper prices without compromising on quality. Levitt [14] claimed that by reducing cost, the global companies automatically increase their profitability. Thus, the cost-effectiveness factor may be accorded higher prominence in weighting over the others, since it has the potentiality of completely crippling the most well-thought out education policy. This assertion finds support in the work of Ollennu and Maloreh-Nyamekye [22] in which the researchers found that some education policies were truncated due to lack of funds. Therefore, the superior cost-effectiveness of the 3-year system over the 4-year is worthy of noting.

In a research work submitted in partial fulfilment of requirements for the award of Doctor of Philosophy degree, Ollennu [21] observed that the research participants, some of whom were protagonists of the 3-year secondary education system and others of the 4-year, unanimously agreed that the stress on existing educational facilities is lower in the 3-year system than the 4-year. Of course, it is obvious that if people are using a facility for a shorter time, the stress on it would be lower than when they use it for a longer period. Similarly, his research participants had no disagreement that a shift from a 3-year to 4-year education system would require an immediate increment of resources to manage the system. These resources include both human and material since there would be more classes of students to handle. However, should the reverse happen, that is, a shift from 4-year to 3-year system, that challenge may not be encountered. Again, the protagonists of both policies were unanimous in their agreement that academic performance was better in the 4-year system than the 3 -year. This viewpoint was supported by the outcome of the quantitative analysis in this study where all the parameters considered for academic performance favoured the 4-year system.

The issue of one system being better at increasing the human capital of graduates than the other, so far has no research data for comparison. However, the likelihood is that the two systems may possess equal potential of increasing the human capital of their products, except to note that the 3-year will arguably churn out manpower for the job market at a faster rate, while the 4-year may produce better matured human resource. In regard to imparting problem-solving abilities to graduates and yielding high living standards for citizenry, the participants of Ollennu's [21] research highlighted no difference in degree of output. This may be due to the fact that the two systems are equal in terms of these characteristics.

The seven identified characteristics of an optimal education system in this study, were converted by the author into parameters for a proposed framework for assessing the viability of an education policy. The proposed framework is outlined in Table 16 below, and used for the comparison of the 3-year and 4-year secondary education policies.

Table 16. Comparison of 3-Year and 4-Year Based on the Ollennu's Optimal Education Framework

\begin{tabular}{|c|l|c|c|}
\hline S/N & Characteristic of Optimal Education System & 3-Year System & 4-Year System \\
\hline 1 & Cost-effectiveness & Yes & No \\
\hline 2 & Low stress on existing facilities & Yes & No \\
\hline 3 & Little additional resources required & Yes & Yes \\
\hline 4 & Higher academic performance & No & Yes \\
\hline 5 & Increased human capital of graduates & Yes & Yes \\
\hline 6 & Problem-solving abilities & Yes & Yes \\
\hline 7 & High living standard of citizenry & & \\
\hline
\end{tabular}


The "Yes" and "No" used in the framework are not absolute. That is, a "Yes" does not mean a foolproof situation nor a "No" means a complete absence of the attribute. They are used in the comparative sense to give an appreciation of which is higher or lower than the other.

From Table 16, the 3-year secondary education policy has more "Yes" than the 4-year. This means that the 3-year secondary education policy with its cost-effectiveness and less stress on existing facilities and resources, appears to be the better fit for the definition of an optimal education system in this study. This may explain why the academically high-performing nations opt for the 3-year system against the 4-year, despite the superior academic performance of the 4-year.

This outcome also supports the recommendation by the protagonists of the 3-year secondary education policy, that Ghana should maintain the 3-year system. From the findings of this study, if the 3-year system is to be maintained, then the teacher-student contact hours would need to be improved to bring it closer to the time-on-task offered by the 4-year system. This will boost academic performance and make it comparable to that of the 4-year system. To achieve this, there may be the need for improved teacher motivation and increased supply of teaching-learning materials.

\section{Recommendations}

\subsection{Recommendations for Choice of Education Policy}

Based on the findings of the study, the author of this study proposes that an education system made of 6-year primary, 2-year junior high school and 4-year senior high school $(6+2+4)$ may be a better alternative to the existing $6+3+3$ (6-year primary, 3-year JHS and 3-year SHS) education system. The author is of the view that this proposal would satisfy those who opt for the 4-year secondary education, but at the same time, will not elongate the total pre-tertiary schooling duration. The maintained 12-year duration of pre-tertiary schooling in this $6+2+4$ system may also be appealing to those who opt for the 3-year system owing to its advantage of reduced length of schooling and, for that matter, cost of education. Should this option be considered, it would be more beneficial to facilitate the transition from primary to junior high school with a standardised formative test to determine the educational attainment of the pupils at that level. This would facilitate the determination of what early interventions may need to be applied to assist the handicapped pupils in their academic progression. Since the test at this level is not summative, there would not be the need for certification.

Additionally, the author recommends that the $6+2+4$ educational system should have an enhanced technical and vocational education options. Furthermore, the system should be designed to drive graduates to acquire a more innovative and problem-solving posture in life. This could make them job-creators rather than job-seekers. To attain this, students should be required to undertake project work on societal problems they have identified and come up with workable solutions. To evaluate learners' educational achievement, a more holistic assessment may be introduced to measure students' problem-solving abilities, not just along the liberal arts lines, but also in the technical and vocational areas.

In the view of the author, the proposed $6+2+4$ education system is superior to Yankah's [27] three-cum-four-year hybrid system since it does not have the challenge of spread of syllabus amongst different groups. It does not also present the complexity that will compel policymakers to seek policy adjustments to cater for the coexistence of different cohorts.

The author believes that the $6+2+4$ education system is a worthwhile venture which could end the debate on which secondary education policy Ghana should follow to optimise and stabilise its educational system.

\subsection{Recommendations for Future Research}

For future research work, instead of using just the core subjects for the study, a combination of the core and some popular elective subjects from each of the programmes of the SHS course may be used in an expanded study to clarify or confirm the findings of this study; and to provide further empirical data to strengthen the research basis for the educational policy process in Ghana. Future researchers may also interrogate the hybrid secondary education and $6+2+4$ pre-tertiary system and confirm how far they could lead to an optimal education system for the country, based on the proposed Ollennu's framework in Table 16.

Through the quantitative analysis in this study, useful information has been provided upon which future researchers could build their study themes in the area of formulation and administration of educational reform policies. The proposed educational policy analysis framework is an addition to knowledge and may also provide a basis for further research work.

\section{Implications of the Findings for Government}

Instead of a straight 3-year or 4-year secondary education, leading to $6+3+3$ or $6+3+4$ education systems, the author made a proposal to the effect that the educational system could follow a 6-year primary, 2-year junior high school and 4-year senior high school $(6+2+4)$ trajectory. This would precipitate as 8-year basic and 4-year secondary education system. The author of this research is of the opinion that the proposal has much merit. It also leaves the length of schooling unchanged. Therefore, it 
may be profitable if the government gave it some consideration should the government decide to move away from the 3-year secondary education policy. Of course, a change of this nature cannot be sudden. Broad-based consultations with stakeholders would have to be undertaken, since it may involve a review of the curriculum, re-training of teachers and re-defining of the use of some infrastructure. For the consultation exercise, the Consultation Model designed by Ollennu and Maloreh-Nyamekye [22] may be followed. To give assurance that the right things are being done, the government will have to set up a committee to critically interrogate the various options including the three-cum-four-year hybrid secondary education system and the existing 3 -year system, with a view to determining their merits and demerits. Probable challenges that may be envisaged include expansion of infrastructure and appreciable improvement of capitation grants and budgetary allocations for running of the schools, should any of the systems with 4-year secondary education be selected.

The study has also provided government with research basis for education policy formulation and implementation, as against the former times when there were no detailed research findings and empirical data to dwell upon for decision-making on this matter.

\section{Conclusions}

The study was designed to interrogate the 3-year and 4-year secondary education policies with the intent of determining which one will be an advantageous education system for Ghana. The findings of the study showed that the 4-year system is more advantageous in relation to academic performance, but the 3-year system is economically more meritorious. However, there is also the option of a $6+2+4$ pre-tertiary education system which the author believes is worthwhile for the country. Therefore, it may be recommended to the Ghanaian government to constitute a committee to investigate the viability of the proposal alongside the findings, through broad-based consultation of educationists, interest groups and other relevant stakeholders. In consideration of the necessity to develop a stable secondary education system for Ghana, it is the candid conviction of the author of this study that the findings of this research will contribute immensely to the attainment of that goal.

\section{REFERENCE}

[1] Adu-Gyamfi, S, Donkoh, WJ, \& Addo, AA 2016, Educational reforms in Ghana: Past and present, Journal of Education and Human Development, vol. 5, no. 3, pp 158-172.
[2] Cheng, YC 2005, A new paradigm for re-engineering education: globalization, localization and individualization, in Cheng, YC 2009, Hong Kong educational reforms in the last decade: reform syndrome and new developments, International Journal of Education Management, vol. 23, no. 1 , pp. $65-86$.

[3] Cheng, YC 2009, Hong Kong educational reforms in the last decade: reform syndrome and new developments, International Journal of Educational Management, vol. 23, no. 1 , pp. $65-86$.

[4] Center for US-Japan Comparative Social Studies (USJP) 2016, Japanese education in the $21^{\text {st }}$ Century. Available from: www.usjp.org. [30 January 2016].

[5] Covey, SR 2004, The 7 habits of highly effective people, Free Press, New York, NY.

[6] Davis, JE \& Jordan, WJ 1994, The effect of school context, structure, and experience on African American males in Middle and High school, Journal of Negro Education, vol. 63 , no. 4, pp. 570-584.

[7] Djangmah, JS \& Akyeampong, DA 1995, 'Senior secondary school duration', Daily Graphic1995, in Djangmah, JS, Addae-Mensah, I \& Agyeman, DK 2009, The case for the 4-year senior high school, A presentation at the National Forum on Duration of Senior High School Education in 2009, Accra, Ghana.

[8] Djangmah, JS 2012, Socio-economic divide in background of children and its reflect in education of children, Presentation paper for Programme for Engmann-Klufio-Datsa Commerative Lectures, pp. 9-10.

[9] Eisenschmidt, E \& Niglas, K 2014, Implementing a design research approach and facilitating networking in the process of educational change, International Journal of Multiple Research Approaches, vol. 8, no. 2, pp. 221-232.

[10] Eshun, FM 2013, The 2007 educational reform and its challenges, Modern Ghana. Available from: https://www. modernghana.com/news. [15 July 2013].

[11] GhanaWeb 2017, The Country Ghana. Available from: www.ghanaweb.com/GhanaHomePage. [22 April 2017].

[12] Glewwe, P \& Muralidharan, K 2015, Improving school education outcome in developing countries: evidence, knowledge gaps, and policy implications, Research on Improving Systems of Education. Available from: www.bsg.ox.ac.uk/RISE_WP-001. [18 April 2018].

[13] Kale-Dery, S 2015, 'B/A tops in exam fraud in 2014 WASSCE', Daily Graphic, 12 March 2015, p. 3.

[14] Levitt, T 1983, The globalization of markets, Harvard Business Review, vol. May-June, reprinted by The McKinsey Quarterly, pp. 2-20.

[15] Malcalm, E 2012, Ghana's Educational Policymakers and Their Impact on Information and Communication Technology Education: A Case Study of a Ghanaian Model Senior High School, $\mathrm{PhD}$ thesis, Ohio University. Available from: OhioLINK [01 December 2016].

[16] Modern Ghana 2009, Why Ghana returned to three-year senior high school. Available from:http://www.moderngha na.com/news. [3 February 2017]. 
[17] National Accreditation Board (NAB), Ghana 2020, Accredited tertiary institutions. Available from: www.nab. gov.gh. [04 April 2020].

[18] National Democratic Congress Manifesto 2008, A Better Ghana: investing in people, jobs and the economy, Manifesto for a Better Ghana, Accra.

[19] Obanya, P 2014, Educationeering, HERN Publishers Plc, Ibadan, Nigeria.

[20] Okrah, K \& Adabor, J 2010, Rethinking free education: how higher education shortchanges and denies access to the less privileged in Africa - the case of Ghana. Michigan Academician, vol. XL, pp. 1-11.

[21] Ollennu, SNN 2017, Three-year versus four-year secondary education reform policy in Ghana: A search for optimal education system, Thesis submitted to the Graduate School of International Management of CASS European Institute of Management Studies, France. (Unpublished).

[22] Ollennu, SNN \& Maloreh-Nyamekye, T. 2019, An Interrogation of Administrative Processes Driving Education Reform Policies in the Secondary Education Sector in Ghana. Universal Journal of Educational Research Vol.7 (12), pp 2773 - 2783. doi: 10.13189/ujer.2019.071227.

[23] Quist, OH, 2003, Transferred and adopted models of secondary education in Ghana: What implications for national development, International Review of Education, vol. 49 , no. 5 .

[24] Ruus, VR, Henno, I, Eisenschmidt, E, Loogma, K, Noorvali, H, Reiska, P \& Rekkor, S 2008, 'Reforms, developments and trends in Estonia education during recent decades', in Eisenschmidt, E \& Niglas, K 2014, Implementing a design research approach and facilitating networking in the process of educational change International Journal of Multiple Research Approaches, vol. 8, no. 2, pp. 221-232.

[25] Trading Economics, 2020, Ghana population 1960-2019 data. Available from www.tradingeconomics.com/ghana/population. [22 April 2020].

[26] Walsh, R 2015, The history of education in England: the $20^{\text {th }}$ Century education in the United Kingdom. Available from: www.know-britain.com. [20 January 2016].

[27] Yankah, K 2016, 'The three-year-four-year school pendulum: towards a stable public policy on senior high school education in Ghana', Lecture presented under the auspices of the Ghana Academy of Arts and Science, Daily Graphic, 5 May, p. 58.

[28] Zame, MY, Hope, WC \& Respress, T 2008, Educational reform in Ghana: the leadership challenge, International Journal of Educational Management, vol. 22, no. 2, pp. 115-128. 